\title{
Renewed Optimism in Persons through South-East Comparative Philosophy
}

Geoff Ashton

University of Colorado at Colorado Springs, USA (gashton@uccs.edu)

DOUGLAS L. BERGER, Encounters of Mind: Luminosity and Personhood in Indian and Chinese Thought, New York: SUNY Press, 2015. viii, 254 pages.

Though the term "comparative philosophy" often brings to mind the relatively recent "East-West" encounter, the experience of cultural difference has helped to invigorate philosophical inquiry throughout human history. Doug Berger's Encounters of Mind highlights this. Over the course of six chapters, Berger follows "the trek of [Vijñānavāda] Buddhism from South to East Asian worlds," tracing the development of the idea of luminous mind and its centrality to the question of personhood in Chinese Buddhism and Neo-Confucianism (5). Rather than simply rehash antiquated debates, he reveals nuances of a thriving dialogue that is pertinent to contemporary discussions of personal identity.

Chapters One and Two respectively examine how ancient Chinese (fifth-third century BCE) and classical Indian traditions (fifth century BCE to sixth century CE) viewed the body in terms of five external sense organs and a sixth, internal organ that surveys and integrates sensations. However, Chinese texts viewed the physical body as conscious (invigorated by qi) and generally emphasized the heart's capacity to develop moral character. By contrast, Indian Brāhminical thinkers restricted consciousness to a transcendent self that inhabits an otherwise unconscious, karmic body-i.e., a body that, along with our psychological dispositions and social duties, gets causally shaped by past actions.

Chapter Three explores the development of the Indian Buddhist school, Vijñānavāda. In deliberate contrast to Brāhminical worldviews, Vijñānavāda rejected notions of a spiritual self. It held that the awareness of continuous identity emerges from constantly changing psychic processes that get distributed across bodily sensations and karmically held together as causal heritages. But how does this framework enable the ultimate goal of Buddhism-liberation from suffering? The Vijñānavāda philosopher, Paramārtha (499-569 CE), theorized psychic seeds that reside in a "storehouse consciousness" (älayavijñana) that persists through causally connected lifetimes, underlies all forms of awareness, but also comprises our original, untainted nature as "luminous mind" (prabhäsvaram cittam). Since awakening to this already perfect mind constitutes liberation itself, freedom from suffering is immediately available to us-for pure luminosity already resides within us in the seeds of mental activities (98).

As Berger clarifies in Chapters Four and Five, Vijñānavāda exerted considerable influence on Chinese Buddhism and Neo-Confucianism. The Huayen Buddhist philosopher, Zongmi (780-841 CE), synthesized the karma and original mind doctrines in order to explain the continuity of the "conscious spirit" across lives and the possibility of liberation. The Chan Buddhist, Linji (d. 866), rejected theoretical speculation and heartpurification, and instead emphasized "genuine" personhood, attentiveness to present experience, and the

Journal of World Philosophies 1 (Winter 2016): 150-151

Copyright $(2016$ Geoff Ashton.

e-ISSN: 2474-1795 • http://scholarworks.iu.edu/iupjournals/index.php/jwp • doi: 10.2979/jourworlphil.1.1.12 
spontaneous manifestation of a "singular, pure luminosity" that "dwells upon" the body and illuminates one's entire environment (141). Meanwhile, Neo-Confucians such as Zhu Xi (c. 1130-1200) and Wang Yangming (1472-1529) identified the Vijñānavāda idea of luminosity with natural coherence (li), which resided in the heart and could be outwardly manifested; recognized that feeling (different than desire) has a basic moral dimension; and emphasized "luminous awareness" (xing min) for their own programs of moral cultivation, respectively calling for achieved attunement to the "patterns $(g e)$ of things $(w u)$ " and realization of "the already-consummate sagehood that resides in a natural heart" $(169,156)$.

If pressed to criticize Encounters of Mind, I would offer the following. Berger analyses the impact of Buddhist thinking on Neo-Confucianism while only telling us how Chinese thought established fertile ground for Buddhism. But how did Chinese philosophies positively alter Buddhist thinking during the Tang and Song periods $\left(7^{\text {th }}-13^{\text {th }}\right.$ centuries)? Berger may anticipate this criticism when he points out that his goal is not a comprehensive analysis of South-East philosophy, but simply to "prompt related lines of inquiry [and] promote enriched dialogue between representatives of South and East Asian philosophical traditions" (11). To that end, the questions that he stirs within readers equally succeed in rousing philosophical inquiry as do his conclusions.

This book succeeds in its ambitions as a work of intellectual history (it adroitly covers vast territories and time periods). But its contributions to cross-cultural philosophy are even more significant. It sharply brings into focus the rough conceptual edges of the idea of luminous mind and the profound meaning that it gives to the question, "what does it mean to be a person?" Perhaps its greatest feature, however, is its sincerity. Paradoxically inspired by Schopenhauer's "pessimism" toward Asian philosophies, this book brackets off what Schopenhauer characterized as the "life-denying" axiologies that have misconstrued these traditions for centuries and uncovers a deep well of optimism underlying them. Berger guides us through worlds of thought that exhibit the same joy of self-discovery that he does. Fittingly, Chapter Six closes the book with a provocation: by engaging in sustained dialogue with these thinkers, that we might wonder what it is like to be in a world where the fragility of life and goodness are recognized, but we can illuminate within ourselves and our communities "a philosophically sophisticated optimism $[\ldots]$ about the possibilities of human achievement" (216).

Geoff Ashton is Assistant Professor of Asian philosophy at the University of Colorado, Colorado Springs. His research focuses on Indian philosophy, Buddhist philosophy, philosophy of religion, and aesthetics. Some of Geoff's most recent publications include “Ardhanārīśvara or 'The Lord of Dance Who is Half-Woman': Performative Liberation and the Divine Androgynous Gender in Kashmir Śaivism" (book chapter in Gender and Indian Philosophy, ed. Veena Howard, New York: Bloomsbury Publishing, forthcoming in 2017) and "From Puzzling Pleasures to Moral Practices: Aristotle and Abhinavagupta on the Aesthetics and Ethics of Tragedy" (co-authored with Sonja Tanner, in Philosophy East and West 66, no. 1, 2016, 1-23). Geoff is currently in the midst of six months of Fulbright research at Jawaharlal Nehru University in Delhi, India.

Journal of World Philosophies 1 (Winter 2016): 150-151

Copyright $(2016$ Geoff Ashton.

e-ISSN: 2474-1795 • http://scholarworks.iu.edu/iupjournals/index.php/jwp • doi: 10.2979/jourworlphil.1.1.12 